\title{
Invasive Malignant Neoplasm
}

National Cancer Institute

\section{Source}

National Cancer Institute. Invasive Malignant Neoplasm. NCI Thesaurus. Code C8505.

Cancer that has spread beyond the layer of tissue in which it developed and is growing into surrounding, healthy tissues. 